\title{
Criminal law sanctions and the Return Directive: the position of illegally staying third-country nationals in the European Union ${ }^{*}$
}

\author{
Aniel Pahladsingh \& Jim Waasdorp
}

\section{Introduction}

In 2015, the number of illegally staying third-country nationals ordered to leave the European Union amounted to 533 395. With around 2.6 million asylum applications in 2015 and 2016 alone, and considering that the first instance recognition rate stands at $57 \%$ in the first three quarters of 2016, Member States may have more than 1 million people to return once their asylum applications have been processed. At the same time, the European Commission states that return rates at European Union level have not improved. While the total return rate from 2014 to 2015 increased from $41.8 \%$ to $42.5 \%$, the rate of effective returns to third countries dropped from $36.6 \%$ to $36.4 \%$. Moreover, if return to Western Balkans is disregarded, the European Union return rate drops further to $27 \%{ }^{1}$

This article focuses on the Return Directive ${ }^{2}$ and discusses the relation between effective returns of illegally staying third-country nationals and the power of Member States ${ }^{3}$ to lay down criminal law sanctions in national legislation such as financial sanctions or imprisonment, as well as to impose these sanctions. We note that the problem may not only relate to criminal law sanctions, but also to other (preliminary) measures entailing a deprivation of liberty, such as pre-trial

* This article is an edited version of J.R.K.A.M. Waasdorp \& A. Pahladsingh, 'Expulsion or Imprisonment? Criminal Law Sanctions for Breaching an Entry Ban in the Light of Crimmigration Law', Bergen Journal of Criminal Law and Criminal Justice 2016 (vol. 4, issue 2), pp. 247-266. All views expressed are strictly personal. Both authors are specialised in European Union law, with a focus on the Return Directive and the entry ban. Aniel and Jim are the authors of the Dutch legal handbook on the entry ban, Het inreisverbod. Op het snijvlak van het vreemdelingenrecht en het strafrecht (The Hague: Sdu Publishers), of which the second edition was published in April 2016. Furthermore, they are the authors of the book Crimmigration law in the European Union. The Return Directive and the entry ban (Oisterwijk: Wolf Legal Publishers), which was published in June 2016. All views are strictly personal. The web adresses were double checked on 3 May 2017.

1 Communication from the European Commission to the European Parliament and the Council of 2 March 2017 on a more effective return policy in the European Union - A renewed Action Plan (COM(2017) 200 final). See also Commission Recommendation of 1 March 2017 on making returns more effective when implementing the Directive 2008/115/EC of the European Parliament and of the Council, C(2017) 1600.

2 Directive 2008/115/EC of the European Parliament and of the Council of 16 December 2008 on common standards and procedures in Member States for returning illegally staying third-country nationals (Official Journal L 348, 24 December 2008, p. 98).

3 The Member States are: all EU Member States (except the United Kingdom and Ireland) and Iceland, Norway, Switzerland and Liechtenstein. 
detention. The use of substantive criminal law as a response to illegal migration is growing. At EU level, this trend is materialised by both the EU legislator and the Member States individually. Vavoula pointed out that EU involvement takes place in a two-fold manner: ${ }^{4}$

1 directly, through harmonization of national legislations; and

2 indirectly, through the case law of the Court of Justice of the European Union (CJEU).

EU legislation regarding human smuggling is an example of the direct involvement of the EU in criminalizing illegal migration. Human smuggling is regulated by Directive 2002/90/EC ${ }^{5}$ which sets out the definitions for the crimes. This directive is accompanied by Framework Decision 2002/946/ $\mathrm{JHA}^{6}$ criminalizing the conducts described in the directive and setting out sanctions. ${ }^{7}$

The case law of the CJEU regarding, for example, criminal law sanctions for breaching an entry ban is an example of the indirect involvement of the EU in criminalizing illegal migration. Entry bans are foreseen in the Return Directive. This directive aims at establishing common standards and procedures to be applied in Member States for returning illegally staying third-country nationals (article 1). We note that in most international fora terms like 'undocumented' or 'irregular' migrants are preferred to describe a person who has no right to stay in a country. However, the Council and the European Commission adopted the terms 'illegal' third-country national and 'illegal' stay in the Return Directive. For that reason, in this article we will use the term 'illegal'. As defined in article 3(6) of the Return Directive, an entry ban is an 'administrative or judicial decision or act prohibiting entry into and stay on the territory of the Member States for a specified period, accompanying a return decision'. This European dimension of an entry ban, expressed, inter alia, in recital (14) of the preamble to the Return Directive, is one of the added European key values of this directive. The conditions for issuing an entry ban are mentioned in article 11 of the Return Directive. Regarding criminal law sanctions, this directive does not in itself preclude national legislation from classifying a breach of an entry ban by an illegally staying third-country national as an offense and laying down criminal law sanctions. However, the European Commission and the CJEU place strict limitations on Member States' power to impose criminal law sanctions. In this article, we will discuss the possibilities and limitations. In paragraph 2 we will analyse the autonomous nature of national criminal law and the return procedure set out in the Return Directive. In paragraph 3 we will discuss the possibilities and limitations

4 Vavoula, 'The interplay between EU immigration law and national criminal law: the case of the Return Directive', in: Mitsilegas et al, Research Handbook on EU Criminal Law, Edward Elgar Publishing 2016, p. 294.

5 Directive 2002/90/EC of 28 November 2002 defining the facilitation of unauthorized entry, transit and residence, Official Journal L 328/17.

6 Framework Decision 2002/946/JHA of 28 November 2002 on the strengthening of the penal framework to prevent the facilitation of unauthorized entry, transit and residence, Official Journal L 328/1.

$7 \quad$ See Vavoula 2016 p. 294. 
for imposing criminal law sanctions. In paragraph 4 we will bring together our findings.

\section{Criminal law sanctions and the Return Directive}

\subsection{The autonomous nature of national criminal law}

In its judgments in Achughbabian ${ }^{8}$ and Sagor, ${ }^{9}$ the CJEU pointed out that the Return Directive is not designed to harmonise in their entirety the rules of Member States on the stay of foreign nationals. Therefore, it does not preclude national legislation from classifying an illegal stay by a third-country national as an offence and laying down criminal law sanctions, including a term of imprisonment. ${ }^{10}$ Neither does the CJEU preclude a third-country national from being placed in detention with a view to determining whether or not his stay is lawful. ${ }^{11}$ Regarding entry bans, the CJEU referred in Celaj ${ }^{12}$ to its judgment in Achughbabian and Sagor. The CJEU stated, by analogy, that the Return Directive does not preclude, in principle, the law of a Member State from classifying the unlawful reentry of a third-country national in breach of an entry ban as an offence and laying down criminal law sanctions to deter and penalize such an infringement. ${ }^{13}$

In our opinion it follows from these judgments that the classification of breaching an entry ban as an offence and the laying down of criminal law sanctions in national legislation are, in principle, matters of the Member States. This shows the autonomous nature of national criminal law. However, according to the CJEU under the Return Directive there are strict limitations for imposing criminal law sanctions by the Member States. These limitations relativise the autonomous nature of national criminal law. In paragraph 2.2 we will first describe the return procedure. Thereafter, in paragraph 2.3 we will discuss the limitations for Member States to impose criminal law sanctions in the view of the European Commission. In paragraph 2.4 we will give a more detailed analysis of the case law of the CJEU.

\subsection{An overview of the return procedure}

In its judgment in El Dridi, ${ }^{14}$ the CJEU summarised the return procedure set out in the Return Directive. Article 6(1) thereof provides, first of all, principally, for an obligation for Member States to issue a return decision against any thirdcountry national staying illegally on their territory. As part of that initial stage of

8 CJEU (Grand Chamber) 6 December 2011, C-329/11, Achughbabian, ECLI:EU:C:2011:807, http:// curia.europa.eu, JV 2012/75 m.nt. B. van Dokkum.

9 CJEU (First Chamber) 6 December 2012, C-430/11, Md Sagor, ECLI:EU:C:2012:777, http://curia. europa.eu, JV 2013/96 m.nt. P. Boeles.

10 Achughbabian (para. 32); Sagor (para. 32).

11 Achughbabian (para. 29).

12 CJEU (Fourth Chamber) 1 October 2015, C-290/14, Celaj, ECLI:EU:C:2015:640, http://curia. europa.eu, JV 2015/309 m.nt. C.H. de Jonge van Ellemeet.

13 Celaj (para. 32).

14 CJEU (First Chamber) 28 April 2011, C-61/11 PPU, El Dridi, ECLI:EU:C:2011:269, http://curia. europa.eu, JV 2011/242 m.nt. P. Boeles, NJB 2011/1091, RvdW 2011/901. 
the return procedure, priority is to be given, except where otherwise provided for, to voluntary compliance with the obligation resulting from that return decision, with article 7(1) of the Return Directive providing that the decision must provide for an appropriate period for voluntary departure of between seven and thirty days. It follows from article 7(3) and (4) of the Return Directive that it is only under particular circumstances, such as where there is a risk of absconding, that Member States may, first, require the addressee of a return decision to report regularly to the authorities, deposit an adequate financial guarantee, submit documents or stay at a certain place or, second, grant a period shorter than seven days for voluntary departure or even refrain from granting such a period. The CJEU noted that in the latter situation, but also where the obligation to return has not been complied with within the period for voluntary departure, article 8(1) and (4) of the Return Directive provides that, in order to ensure effective return procedures, the Member State which has issued a return decision against an illegally staying third-country national carries out the removal by taking all necessary measures including, where appropriate, coercive measures, in a proportionate manner and with due respect for, inter alia, fundamental rights. It is only where, in the light of an assessment of each specific situation, the enforcement of the return decision, in the form of removal, risks being compromised by the conduct of the third-country national concerned that Member States may deprive that person of his liberty and detain him. ${ }^{15}$

In El Dridi, the CJEU concluded from the foregoing that the Return Directive provides for the order of the various stages in the procedure for returning illegally staying third-country nationals, corresponding to a gradation of the measures to be taken into order to enforce the return decision, a gradation which goes from the measure which allows the person concerned the most liberty (i.e. granting a period for his voluntary departure), to measures which restrict that liberty the most (i.e. detention in a specialised facility). Throughout those stages, the principle of proportionality must be observed. With regard to the possible deprivation of liberty, the CJEU pointed out that this measure is strictly regulated by articles 15 and 16 of the Return Directive. In particular, any detention pending removal is to be as short a period as possible and its length should not exceed that required for the purpose pursued. ${ }^{16}$

\section{Criminal law sanctions: possibilities and limitations}

\subsection{The view of the European Commission}

According to article 2(2)b of the Return Directive Member States are free (thus not obliged) to decide not to apply this directive to third-country nationals:

- who are subject to return as a criminal law sanction or as a consequence of a criminal law sanction, according to national law; or

- who are the subject of extradition procedures. 


\section{- Criminal law sanction according to national law}

As the European Commission clarified in the Return Handbook in Filev and Osmani ${ }^{17}$ the CJEU expressly clarified that offences against the provisions of national law on narcotics and convictions for drug trafficking may be cases to which the derogation of article 2(2)(b) of the Return Directive is applicable. The CJEU confirmed in the case of Achughbabian that this derogation cannot be used without depriving the Return Directive of its purpose and binding effect, to thirdcountry nationals who have committed only the offence of illegal staying. Minor migration related infringements, such as mere irregular entry or stay, cannot justify the use of this derogation. ${ }^{18}$

\section{- Extradition procedures}

Extradition procedures are not necessarily related to return procedures. The basic 1957 Council of Europe Convention circumscribes extradition as surrendering persons against whom the competent authorities of the requesting party are proceeding for an offence or who are wanted by the said authorities for the carrying out of a sentence or detention order. The European Commission pointed out that there may, however, be overlap and this derogation aims at making clear that Member States have the option not to apply the procedural safeguards contained in the Return Directive when carrying out return in the context of extradition procedures. ${ }^{19}$

\section{- Penal sanctions in relation to infringements of migration rules}

Member States are free to lay down penal sanctions in relation to infringements of migration rules, provided such measures do not compromise the application of the Return Directive. According to the European Commission it is up to national law to determine which types of infringements of migration rules are penalized. ${ }^{20}$ Member States are free to impose penal sanctions following national rules of criminal procedure, on third-country nationals to whom the return procedure established by the Return Directive has been applied and who are illegally staying in the territory of a Member State without there being any justified ground for non-return. According to the European Commission justified reasons for nonreturn may:

- either be reasons outside the scope of influence of the returnee (such as delays in obtaining necessary documentation from third countries caused by bad cooperation of third country authorities, crisis situation in country of return making safe return impossible, granting of formal postponement of return/toleration status to certain categories of returnees); or

17 CJEU (Fourth Chamber) 19 September 2013, C-297/12, Filev and Osmani, ECLI:EU:C:2013:569, http://curia.europa.eu, JV 2013/376 m.nt. G.N. Cornelisse.

18 EC 1 October 2015, Common 'Return Handbook' to be used by Member States' competent authorities when carrying out return related tasks, COM(2015) 6250 final, p. 18 (hereinafter referred to as: $\operatorname{COM}(2015) 6250$ final). Ibid.

$20 \operatorname{COM}(2015) 6250$ final, p. 19. 
- reasons within the sphere of the returnee which are recognised as legitimate or justified by Union or national law (e.g. health problems or family reasons leading to postponement of removal, pending appeal procedure with suspensive effect, decision to cooperate with authorities as witness). ${ }^{21}$

The European Commission furthermore explained that the mere subjective wish to stay in the EU can never be as such considered as a "justified reason for nonreturn'. Non-justified reasons for non-return may also be reasons within the scope of influence of the returnee which are not recognized as legitimate or justified by Union or national law, such as lack of cooperation in obtaining travel documents, lack of cooperation in disclosing ones identity, destroying documents, absconding and hampering removal efforts. ${ }^{22}$

Penal sanctions aimed at dissuading non-removable returnees who have no justified reasons for non-return from remaining illegally must comply with fundamental rights, particularly those guaranteed by the European Charter of Human Rights and the Charter of Fundamental Rights, and shall comply with the proportionality principle. The maximum limit for depriving the liberty of non-cooperating returnees has been limited by the Return Directive to 18 months. The European Commission considered that Member States should not impose imprisonment under penal law after the expiry of 18 months (or the maximum allowed under relevant national law) on returnees who committed no other offence than illegal stay or non-cooperation. ${ }^{23}$

\subsection{The view of the CJEU}

In its settled case law (El Dridi, Achughbabian, Sagor, Filev and Osmani, Celaj, and $A_{f f u m}{ }^{24}$ ) the CJEU more or less explicitly emphasized that Member States may not apply rules, even criminal law rules, which are liable to jeopardise the achievement of the objectives pursued by a directive and, therefore, deprive it of its effectiveness. Regarding, more specifically, the Return Directive, in El Dridi the CJEU pointed out that Member States may not, in order to remedy the failure of coercive measures adopted in order to carry out forced removal pursuant to article 8 (4) of that directive, provide for a custodial sentence on the sole ground that a third-country national continues to stay illegally on the territory of a Member State after an order to leave the national territory was notified to him and the period granted in that order has expired. Such a penalty risks jeopardizing the attainment of the objective pursued by the Return Directive. ${ }^{25}$ In particular, the CJEU pointed out that national legislation, such as that at issue in the Italian case of El Dridi, is liable to frustrate the application of the measures referred to in arti-

23 Ibid.

24 CJEU (Grand Chamber) 7 June 2016, C-47/15, Affum, ECLI:EU:C:2016:408, http://curia.europa. eu, JV 2016/236 m.nt. E.R. Brouwer.

25 See Raffaelli, 'The returns directive in the light of the El Dridi judgment', Perspectives on Federalism Vol. 3 (2011) pp. 32-45. 
cle 8(1) of the Return Directive and delay the enforcement of the return decision. ${ }^{26}$

In Achughbabian, the CJEU recalled its judgment in El Dridi. The CJEU pointed out that the expressions 'measures' and 'coercive measures' contained in the Return Directive refer to any intervention which leads, in an effective and proportionate manner, to the removal of the person concerned. Detention of the person concerned, for a maximum duration of eighteen months, is permitted only for the purposes of preparing and permitting the removal. According to the CJEU, the imposition and implementation of a sentence of imprisonment during the course of the return procedure does not contribute to the realisation of the removal which that procedure pursues. On the contrary, such imprisonment is liable to delay the return and thereby undermines the effectiveness of the Return Directive. Therefore it does not constitute a 'measure' or 'coercive measure' within the meaning of the Return Directive. ${ }^{27}$

In Achughbabian, the CJEU also clarified the scope of the application of article 2(2)(b) of the Return Directive. This provision allows Member States not to apply the Return Directive to third-country nationals who are subject to return as a criminal law sanction or as a consequence of a criminal law sanction according to national law, or who are the subject of extradition procedures. According to the CJEU, however, this provision clearly cannot be interpreted as allowing Member States not to apply the Return Directive to third-country nationals who have committed only the offence of illegal stay, since such an interpretation would deprive the Return Directive of its purpose and binding effect. Thus, in Achughbabian the CJEU clarified that criminal law sanctions may only be adopted once the return procedure is exhausted, if the adoption of coercive measures do not enable the removal of the immigrant to take place, and only so far as there is no justified ground for non-return. Finally, the imposition of such sanctions is subject to full compliance with fundamental rights, and in particular with the rights recognised by the ECHR. ${ }^{28}$

In Sagor, the CJEU upheld its judgments in El Dridi and Achughbabian pursuant to the fact that the Return Directive would be undermined if, after establishing that a third-country national is staying illegally, the Member State in question were to preface the adoption or implementation of the return decision with a criminal prosecution which could lead to a term of imprisonment during the course of the return procedure, a step which would risk delaying the removal. ${ }^{29} \mathrm{Next}$, in Sagor the CJEU observed that the return measures are not delayed or impeded by a criminal prosecution such as that brought against Mr Sagor, since the national legislation in question allows the return to be achieved regardless of the criminal prosecution, even without that prosecution having come to an end. Nor is the imposition of a fine liable to impede the implementation of the return proce-

\section{Achughbabian (para. 37).}

Achughbabian (paras. 41, 46, 48-49). See also on this Raffaelli, 'Case note: the Achughbabian case. Impact of the return directive on national criminal legislation, New York University School of Law 2011, p. 8.

Sagor (para. 33). 
dure. ${ }^{30}$ Also, the possibility given to the criminal court of replacing the fine with an expulsion order accompanied by an entry ban, as regards Italy, in situations where it is possible immediately to effect the return of the individual concerned, is not contrary to the Return Directive. Indeed, the Return Directive allows Member States - on the basis of an individual examination of the situation of the individual concerned - to impose expulsion without granting a period for voluntary departure where there is a risk that the individual may abscond in order to avoid the return procedure. ${ }^{31}$ Lastly, in Sagor the CJEU observed that Member States are required, under their duty of loyalty and the requirements of effectiveness referred to in the Return Directive, to carry out the removal as soon as possible. Where a fine is replaced by a home detention order, the CJEU found that that order, imposed in the course of the return procedure, does not help to achieve the physical transportation of an illegally staying third-country national out of the Member State concerned. On the contrary, the home detention order may delay and thus impede measures such as deportation and forced return by air, which can be used to achieve removal. In this respect, the CJEU pointed out that such a risk of undermining the return procedure is present in particular where the applicable legislation does not provide that the enforcement of a home detention order imposed on an illegally staying third-country national must come to an end as soon as it is possible to effect that person's removal. ${ }^{32}$

In Filev and Osmani, the CJEU ruled that article 11(2) of the Return Directive must be interpreted as precluding a breach of an entry ban in the territory of a Member State, which was handed down more than five years before the date either of the re-entry into that territory of the third-country national concerned or of the entry into force of the national legislation implementing that directive, from giving rise to a criminal law sanction, unless that national constitutes a serious threat to public order, public security or national security. ${ }^{33}$ This precludes a continuation of the effects of entry bans of unlimited length made before the date on which the Return Directive became applicable, beyond the maximum length of entry bans laid down by that provision, except where those entry bans were made against third-country nationals constituting a serious threat to public order, public security or national security. ${ }^{34}$

According to the CJEU in Filev and Osmani, the Return Directive must be interpreted as precluding Member States from providing that an expulsion or removal order which predates by five years or more the period between the date on which that directive should have been implemented and the date on which it was implemented, may subsequently be used as a basis for criminal proceedings, where that order was based on a criminal law sanction within the meaning of article 2(2)(b) of that directive and where Member States exercised the discretion provided for under that provision. ${ }^{35}$ The consequence of the use by Member States of the dis-

30 Sagor (paras. 36-37).

31 Sagor (para. 41).

32 Sagor (paras. 44-45).

33 Filev and Osmani (para. 44).

34 Filev and Osmani (paras. 44-45).

35 Filev and Osmani (paras. 50-52). 
cretion provided for in article 2(2)(b), at the latest upon expiry of the period for implementing that directive, is that third-country nationals referred to therein will not at any time fall within the scope of that directive. In contrast, in so far as a Member State has not yet made use of that discretion after expiry of the said time period for implementation, in particular because of the fact that it has not yet implemented the Return Directive in national law, it may not avail itself of the right to restrict the scope of the persons covered by that directive pursuant to article 2(2)(b) thereof with regard to those persons who were already able to avail themselves of the effects of that directive. ${ }^{36}$

In Celaj, the CJEU stated that the criminal proceedings at issue involved the situation of an illegally staying third-country national to whom the common standards and procedures established by the Return Directive were applied in order to put an end to his first illegal stay in the territory of a Member State and who then re-entered the territory of that State in breach of an entry ban. This brought the CJEU to the conclusion that the circumstances of the case of Celaj are clearly distinct from those in the cases that led to the judgments in El Dridi and Achughbabian in which illegally staying nationals of the third countries concerned were subject to a first return procedure in the Member State in question. ${ }^{37}$ In addition, the CJEU recalled that it already held in its judgment in Achughbabian that the Return Directive does not preclude criminal law sanctions being imposed on third-country nationals to whom the return procedure established by that directive has been applied and who are illegally staying in the territory of a Member State without there being any justified ground for non-return. This, following national rules of criminal procedure. There is thus, according to the CJEU, all the more reason to consider that the Return Directive does not exclude the possibility for Member States to lay down criminal law sanctions against illegally staying third-country nationals for whom the application of the procedure established by that directive resulted in them being returned and who then re-enter the territory of a Member State in breach of an entry ban (see also paragraph 3.1 above). However, the imposition of a criminal law sanction is only admissible on the condition that the entry ban issued against the third-country national concerned complies with Article 11 of the Return Directive. ${ }^{38}$ The imposition of such a criminal law sanction is moreover subject to full observance both of fundamental rights, particularly those guaranteed by the ECHR and, as the case may be, of the UN Refugee Convention, in particular Article 31(1) thereof. ${ }^{39}$ When third-country nationals re-enter the territory of a Member State in breach of an entry ban, Majcher

37 The 'distinction' argument had been advanced by the European Commission and intervening governments during the proceedings. They stressed that the circumstances in re-entry cases are distinct because penal sanctions could be imposed to dissuade migrants from breaching re-entry bans (Opinion AG Szpunar of 28 April 2015, C-290/14, Celaj, ECLI:EU:C:2015:640, para. 46). See for more critics on the distinction argument Majcher, 'The CJEU's Ruling in Celaj: Criminal penalties, entry bans and the Returns Directive', (http://eulawanalysis.blogspot.nl/2015/10/the-cjeus -ruling-in-celaj-criminal.html). 
points out that Member States may use other available methods to punish the breach, such as an extension of an existing ban. More generally, criminalization of breaches of (administrative) immigration law risks creating a conflation between (non-punitive) immigration law and criminal law, which may lead to negative consequences for migrants and an undue overburden to the criminal justice system. According to Majcher, the ruling in Celaj seems to compromise the effectiveness of the Return Directive in order to accord discretion to Member States that apply their domestic criminal provisions to deter and punish migrants for breaching an entry ban. ${ }^{40}$

According to the CJEU in Affum, a preliminary point to note is that the main proceedings relate to the situation of a third-country national who illegally entered the territory of a Member State forming part of the Schengen Area by crossing a common border of that state and another Member State also forming part of that area, and who was then intercepted when she was preparing to go to the territory of a third Member State, which does not form part of that area. ${ }^{41}$ It should be noted that, as regards the scope of the Return Directive, article 2(1) provides that the Return Directive applies to third-country nationals staying illegally on the territory of a Member State. The concept of 'illegal stay' is defined in article 3(2) of this directive as 'the presence on the territory of a Member State, of a third-country national who does not fulfil, or no longer fulfils the conditions of entry as set out in article 5 of the Schengen Borders Code or other conditions for entry, stay or residence in that Member State. ${ }^{\prime 2}$ Since a third-country national travelling on a bus across the territory of a Member State in breach of the conditions for entry, stay or residence is clearly present on its territory, the CJEU concluded that he is staying there illegally, within the meaning of article 3(2) of the Return Directive, and falls within that directive's scope, in accordance with article 2 thereof. ${ }^{43}$ Consequently, such nationals must be subject to the return procedure laid down by the Return Directive for the purpose of their removal, as long as their stay has not, as the case may be, been regularised.

The CJEU also stated in Affum that the Return Directive does not preclude an illegally staying national of a non-EU country from being imprisoned when the return procedure has been applied and the national re-enters the territory of the Member State in breach of an entry ban (see also the judgment in Celaj above). ${ }^{44}$ Nor does the Return Directive preclude nationals of a non-EU country from being placed in administrative detention with a view to determining whether or not their stay is legal. ${ }^{45}$ Finally, it must be made clear that the Return Directive does not prevent Member States from being able to impose a sentence of imprisonment to punish the commission of offences other than those stemming from the mere fact of illegal entry, including in situations where the return procedure has

40 See Majcher, 'The CJEU's Ruling in Celaj: Criminal penalties, entry bans and the Returns Directive', (http://eulawanalysis.blogspot.nl/2015/10/thecjeus-ruling-in-celaj-criminal.html).

41 Affum (para. 44).

42 Affum (para. 47).

43 Affum (para. 48).

44 Affum (para. 64).

45 Affum (para. 53). 
not yet been completed. ${ }^{46}$ Furthermore, in Affum the CJEU pointed out that the exceptions provided for by the Return Directive ${ }^{47}$ do not permit Member States to exclude nationals such as Ms Affum from its scope on the ground that they have illegally crossed an internal border of the Schengen Area (in this case, the Franco-Belgian border) or have been arrested when trying to leave that area (the United Kingdom does not form part of the Schengen Area). ${ }^{48}$ Moreover, the fact that Ms Affum was the subject of a procedure for readmission into the Member State from which she came (Belgium) does not render the Return Directive inapplicable to her case. Readmission simply has the effect of transferring the obligation to apply the return procedure to the Member State responsible for taking the national back (in this case, Belgium). To imprison an illegally staying national of a non-EU country would delay the triggering of the return procedure and that national's actual removal and would thereby undermine the Return Directive's effectiveness. ${ }^{49}$ In Affum the CJEU concluded that, for the same reasons as those set out in its decision in Achughbabian, Member States cannot permit nationals of non-EU countries in respect of whom the return procedure established by the Return Directive has not yet been completed to be imprisoned merely on account of illegal entry, resulting in an illegal stay, as such imprisonment is liable to thwart the application of that procedure and delay return, and thereby to undermine the Return Directive's effectiveness. This does not, however, prevent Member States from being able to impose a sentence of imprisonment to punish the commission of offences other than those stemming from the mere fact of illegal entry, including in situations where the return procedure has not yet been completed. This judgement will have effect on Member States where imprisonment on the account of illegal staying is possible. Such domestic legislation has to be changed in the way that an individual assessement has to be made by the domestic authorities regarding the situation of the illegal staying third-country national and the possibility of imprisonment. ${ }^{50}$

Affum (para. 65).

47 Under the Return Directive, Member States may decide not to apply the directive to nationals of non-EU countries who are subject to a refusal of entry in accordance with article 13 of the Schengen Borders Code, or who are apprehended or intercepted by the competent authorities in connection with the irregular crossing by land, sea or air of the external border of a Member State and who have not subsequently obtained an authorisation or a right to stay in that Member State.

48 Affum (para. 78).

49 Affum (para. 88).

50 See Picon, Criminalising Hope. Human Rights Implications of the Criminalization of Irregular Immigration in EU Member States and the EU, European Inter-University Centre for Human Rights and Democratisation 2010, p. 28: '(...) the 23 countries do provide for criminal penalties for TCN [third-country nationals, JW/AP] who have illegally entered or who are illegally staying in their territory, in a broad sense'. 


\section{Findings}

We conclude that there is an overlap between immigration law and criminal law in the area of the Return Directive and the entry ban foreseen thereof. A recent example is the attack in Berlin (Germany) on 19 December 2016 by an illegal third-country national named Anis Amri. He was a Tunisian failed asylum seeker. A truck was deliberately driven into the Christmas market beside Kaiser Wilhelm Memorial Church at Breitscheidplatz in Berlin. This terroristic attack left 12 people dead and 56 others injured. One of the victims was the truck's original driver, Eukasz Urban, who was found shot dead in the passenger seat. Four days after the attack Anis was killed in a shootout with police near Milan in Italy. An initial suspect was arrested and later released due to lack of evidence. ${ }^{51}$ If the German authorities would have arrested Anis alive the legal question could arise whether expulsion or imprisonment was prefered. In this specific situation we draw the attention to the importance of article 2(2)b of the Return Directive, according to which the Member States are free to decide not to apply the Return Directive to third-country nationals who are subject to return as a criminal law sanction or as a consequence of a criminal law sanction, according to national law. Offences against the provisions of the national law such as violence and killing of people, which are related to the public order and national security, are cases in our view to which this derogation could be applied. That means that the German authorities would have had the competence to choose for imprisonment instead of expulsion.

Another point of attention regarding the effective return of illegally staying third country nationals is the following. We support the initiative of the European Commission with the proposed changes regarding the registration of entry bans by the Member States in the Schengen Information System (SIS). It will become mandatory to enter alerts in SIS in cases where an entry ban has been issued to an irregularly staying third-country national in accordance with the Return Directive in order to deny entry to the Schengen area during a defined period of time starting from the moment of departure of third-country national concerned. ${ }^{52}$

The findings of the evaluation of the European Commission in 2014 show that there are laws in place criminalizing illegal entry and/or stay, in different forms, in the majority of Member States. ${ }^{53}$ We point out that the Return Directive does not in itself preclude national legislation from classifying a breach of an entry ban as an offence and laying down criminal law sanctions such as financial sanctions and imprisonment. ${ }^{54}$ Criminal law matters remain, in principle, a Member State competence, with each Member State free to adopt criminal law sanctions in order to deter third-country nationals from remaining illegally on their terri-

51 A. Pohlers, 'Sicherheitskreise: Festgenommener ist Afghane oder Pakistani', Verlag Der Tagesspiegel GmbH (20 December 2016).

52 Proposal for a REGULATION OF THE EUROPEAN PARLIAMENT AND OF THE COUNCIL on the use of the Schengen Information System for the return of illegally staying thirdcountry nationals of 21 December 2016, COM(2016) 881 final.

53 EC 28 March 2014, EU return Policy, COM(2014) 199 final, p. 24.

$54 \operatorname{COM}(2015) 6250$ final, p. 62. 
tory. ${ }^{55}$ However, we recall that Member States may not impose criminal law sanctions which are liable to undermine the application of the common standards and procedures established by the Return Directive and thus to deprive it of its effectiveness (the principle of proportionality in EU law).

There is a significant role for the CJEU in practice as regards references from national courts concerning the Return Directive. This directive attracted more references to the CJEU than most EU immigration or asylum measures. ${ }^{56}$ While the case law of the CJEU on the whole has interpreted the Return Directive more liberally than its wording might suggest, it has focused more on the objective of efficient expulsion, rather than on illegal migrants' human rights. The reason for this focus is that it is the task of the national authority and finally of the national court to make the proportionality test with full observance of fundamental rights. As a directive leaves space for the Member States this can lead to certain differences between the Member States regarding criminal sanctions when illegally staying third-country nationals breach an entry ban. We note that these differences can be seen through the amount of a fine or through the duration of imprisonment.

The European Commission and the CJEU confirmed the limits that EU law places upon national criminal law and found a way to apply the protective provisions of EU law to third-country nationals. It makes it increasingly hard for Member States to evade the control of EU institutions and law when they make criminalization choices in the field. We note that in a broad sense it is positive that the Member States are not allowed to provide for criminal sanctions for third-country nationals just because they illegally entered or are staying illegally in their territory (see Affum). ${ }^{57}$ In this example the migrants as such are not criminalised. However, only under strict and limited conditions Member States are allowed to impose criminal law sanctions. The objective of the Return Directive is the return of the illegal migrant instead of punishing him because of the illegal presence. This is also in line with the preamble to the Return Directive. This preamble gives a number of fundamental principles which underpin the legislation as a whole and which therefore should be taken into account in the implementation of its provisions. For example, recital (6) of the preamble and article 11 of the Return Directive assert that entry bans should be issued on a case-by-case basis and based on objective criteria, implying that consideration should go beyond the mere fact of an illegal stay. As regards human rights, the Return Directive and the case law of the CJEU express that they comply with the EU's fundamental rights obligations (recital (24) of the preamble and Celaj). Explicit references are made to Member States' duties under the ECHR and, in asylum related measures, to the UN Refugee Convention (recital (23) of the preamble). incestuous relationship', (via http://eumigrationlawblog.eu).

56 See Peers, 'The EU's Returns Directive: Does it improve or worsen the lives of irregular mirgrants?', (http://eulawanalysis.blogspot.nl/2014/03/the-eus-returns-directive-does-it.html). 
However, the recognition of these commitments does not appear to influence, in practice, the approach towards criminalization. In this respect, we point at the Evaluation on the application of the Return Directive, commissioned by the European Commission and the European Migration Network's study on Good Practices in the return and reintegration of irregular migrants. These reports show that the legislation of almost 40 percent of the Member States provides for an automatic application of entry bans on all return decisions. This automatic application is, in our opinion, a major point of concern. Recitals (6) and (14) of the preamble and article 11(2) of the Return Directive stipulate that an entry ban shall be based on objective criteria and that the length of an entry ban shall be determined with due regard to all relevant circumstances of the individual case (see also Filev and Osmani). Member States which impose criminal law sanctions for breaching an entry ban issued against an illegally staying third-country national should respect the case law of the CJEU. In that perspective we advise that the European Commission should take action if a Member State fails to comply with these provisions of the Return Directive, especially because of the weak position of the illegally staying third-country national in society and the fact that fundamental rights, inter alia, the right of freedom (article 6 Charter of Fundamental Rights of the EU), are at stake. ${ }^{58}$ Furthermore we point out that there is an important role for the national courts to apply the case law of the CJEU in these criminal cases and to protect the rights of illegally staying third-country nationals. The centrality of the principle of proportionality in EU law taken together with the fact that the EU legal system is capable of influencing domestic legal systems in an unmediated manner, the role of litigation should not be underestimated. ${ }^{59}$ In national procedures questions will arise about the proportionality of the specific criminal law sanction breaching an entry ban such as the duration of the imprisonment or the amount of the fine.

\section{Conclusion}

The relation between immigration law and criminal law, and in particular the compatibility of national penal measures imposed as a punishment for breaching an entry ban is developed by the European Commission and the CJEU. In the cases touching upon this issue, the CJEU assessed whether the Return Directive allows Member States to penalize non-compliance with a return order or an illegal stay itself with imprisonment (El Dridi, Achughbabian and Affum respectively) or home detention (Sagor) as a criminal law penalty. The CJEU clearly concluded that Member States may not impose criminal law sanctions liable to jeopardise the attainment of the objectives pursued by the Return Directive and thus to

58 EC 28 March 2014, EU return Policy, COM(2014) 199 final, p. 24: 'The Commission is following the situation closely and has already launched EU Pilot procedures against certain Member States.'

59 See the comparison with detention: Cornelisse, 'The Constitutionalisation of Immigration Detention: Between EU Law and the European Convention on Human Rights', Global Detention project, Working Paper No. 15, October 2016, p. 13. 
deprive it of its effectiveness (the principle of proportionality in EU law). This means that criminal law sanctions may not be imposed if it hampers or delays the return of illegally staying third-country nationals. By extension, in Celaj the CJEU ruled that the Return Directive does not exclude the possibility for Member States to lay down criminal law sanctions against illegally staying third-country nationals for whom the application of the procedure established by that directive resulted in them being returned and who then re-entered the territory of a Member State in breach of an entry ban. However, the CJEU added that the imposition of a criminal law sanction is admissible only on the conditions that the entry ban complies with article 11 of the Return Directive and that the imposition is subject to full observance of both fundamental rights and, as the case may be, of the UN Refugee Convention. ${ }^{60}$

In Affum, the CJEU formulated three situations in which Member States are allowed to impose a criminal law sanction against illegally staying third-country nationals when breaching an entry ban:

1 when the third-country national has previously been subject to a return procedure and continues to stay illegally on the territory of the Member State with no justified ground (see also Achughbabian);

2 when a return procedure has been applied against a third-country national and the national re-enters the territory of the Member State in breach of an entry ban (see also Celaj);

3 Member States are allowed to impose a sentence of imprisonment to punish the commission of offences other than those stemming from the mere fact of illegal entry, including in situations where the return procedure has not yet been completed (Affum).

The use of the instrument of the entry ban and the imposition of criminal law sanctions for breaching an entry ban may be efficient regarding the return of illegally staying third-country nationals. However, we advise Member States to take into account other aspects such as the serious costs to non-citizens, family members, employers, and the community. We also suggest that Member States evaluate the effectiveness of the imposition of criminal law sanctions as an extra measure for the return of illegally staying third-country nationals.

As the European Commission stands ready to launch a revision of the Return Directive we suggest that that the imposition of criminal sanctions for breaching an entry ban will be codified in provisions in the revised Return Directive. ${ }^{61}$ Inspiration for the provisions can be found in the case law of the CJEU.

60 EC 28 March 2014, EU return Policy, COM(2014) 199 final, p.24: 'The above-mentioned rulings have resulted in a wide range of changes to national legislation in the countries examined and several Member States have recently changed their legislation as a consequence of this jurisprudence.'

61 Communication from the European Commission to the European Parliament and the Council of 2 March 2017 on a more effective return policy in the European Union - A renewed Action Plan (COM(2017) 200 final), p.4. 
Finally, our findings show that the position of illegal third-country nationals and the power of the Members States to impose criminal sanctions are very topical and that the main stakeholders in this area should pay due consideration to core the fundamental rights of illegally staying third-country nationals. ${ }^{62}$

62 See A. Pahladsingh, Crimmigration law in the European Union (Part 2). The Return Directive: return decision and detention, Oisterwijk: Wolf Legal Publishers 2016, p. 267. 